\title{
IMPLEMENTATION OF DISCOVERY LEARNING METHODS TO IMPROVE SCIENCE SKILLS IN KINDERGARTEN B CHILDREN
}

\author{
Kevin William Andri Siahaan'1, Uci Nursanty Haloho², Maria Paulina Angel Raja Guk-guk², \\ Fitri Riana Panjaitan ${ }^{4}$ \\ ${ }^{1}$ Faculty of Teacher Training and Education, HKBP Nommensen Pematangsiantar University \\ email: kevinsiahaan52@gmail. com \\ ${ }^{2}$ Faculty of Teacher Training and Education, HKBP Nommensen Pematangsiantar University \\ email: ucihaloho90@gmail. com \\ ${ }^{3}$ Faculty of Teacher Training and Education, HKBP Nommensen Pematangsiantar University \\ email: indigohyuuga90@gmail.com \\ ${ }^{4}$ Faculty of Teacher Training and Education, HKBP Nommensen Pematangsiantar University \\ email: fitripanjaitan587@gmail.com
}

\begin{abstract}
The implementation of science learning activities in Pematangsiantar City has not been optimal. Most of the teachers have not developed and used learning tools with the discovery learning method. The research objective was to determine the application of the discovery learning method to the science skills of kindergarten children through a scientific approach. The research method is quasi-experimental. To determine the effect of the application of the discovery learning method, learning was carried out in two classes, the experimental class and the control class. The results showed that there were differences in the value of science skills in the experimental class with the application of the discovery learning method with a comparison of the science skills scores of 24.64 before being given treatment and 29.92 after being given treatment. The application of discovery learning methods to science skills needs to be assisted and guided thoroughly.
\end{abstract}

Keywords: discovery learning, science skills, kindergarten

\begin{abstract}
Abstrak: Pelaksanaan kegiatan pembelajaran IPA di Kota Pematangsiantar belum maksimal. Sebagian besar guru belum mengembangkan dan menggunakan perangkat pembelajaran dengan metode discovery learning. Tujuan penelitian untuk mengetahui penerapan metode discovery learning pada keterampilan IPA anak taman kanak-kanak melalui pendekatan saintifik. Metode penelitian adalah eksperimen semu. Untuk mengetahui pengaruh penerapan metode discovery learning ini, pembelajaran dilakukan di dua kelas, kelas eksperimen dan kelas kontrol. Hasil penelitian menunjukkan bahwa terdapat perbedaan nilai keterampilan IPA di kelas eksperimen dengan penerapan metode discovery learning dengan perbandingan nilai keterampilan IPA 24,64 sebelum diberikan perlakuan dan 29,92 setelah diberi perlakuan. Penerapan metode discovery learning pada keterampilan IPA perlu dibantu dan dibimbing secara menyeluruh.
\end{abstract}

Kata Kunci :discovery learning,, keterampilan IPA, taman kanak-kanak

\section{INTRODUCTION}

The student in kindergarten is learning by doing and learning while playing. In accordance with its development, a kindergarten teacher must be super creative to dig interest and to ensure that children happy, quiet, and comfortable that requires an innovation. One innovation today to maximize the potential of children is through science 
skills. Learning activities by teachers are more oriented towards to a child in learning activities. The use of new strategy invention the child gets to learn any of its discovery, developed by themself. It is called think, analyze solving the problems of their own. Habituation will be applied such good life. This method has links with science increase skill.

An implementation early childhood education one of them institutions are kindergarten provide services education, especially of children aged 4 to 6 years. Learning activities in a kindergarten referring to permendiknas no. 582009 about standard early childhood education. In the regulation mentioned that their experiences in the early childhood education (paud) have to take the level of achievement of the development of which includes five major aspects the development of namely the development of religious values and moral, motor, cognitive, language and social emotional. Of the each institution can develop in accordance with their condition in the agency.

Early childhood education was a conscious, to facilitate growth physical and spiritual children, skills which is done through the provision of, experience the rich and balance stimuly. The effort conducted integrally and thoroughly. Early childhood development is obliged to all school age will be the millennium development goal this (2005). It is seen that education is the best single development investment can make a country. Education contributes to better health, higher income and registration increase in community life (Catherine, 2012: 48).

Early childhood is the children who was born to the age of eight years. Age is the very decisive in the formation of character and personality the (Sujiono, 2009: 7). An early age is the age at which children had developed and skills rapidly. An early age called (golden age). Balanced and nutritious food intensive stimulation is needed for growth and these skills.

Early childhood education especially kindergarten is basically education is provided in order to facilitate growth and skill he thoroughly or emphasis on the development of all aspects of the personality of children is as raised by Anderson (1993) in Masitoh (2005: 2), early childhood education is based on a number of methodical didactic consideration the aim of which is provide opportunities for development of children personality'. It means, education kindergarten giving hope to develop, child personality hence education for early childhood especially in kindergarten needs to provide various activities when it can develop various aspects of the skills.

Curriculum to early childhood or kindergarten should really meet the needs of a child in accordance with the skill and must be designed to make kids expand their full. Learning early childhood or kindergarten oriented learning is not playing, learning through play learning skills oriented more giving chances to children to can learn by appropriate ways. The most appropriate approach is learning child-centered.

In this case, required a formula the curriculum adapted to the process of growth and it skill. It is important to note that in age 4 to 6 years, children's skill is very fast. Such as physical skill, as increase in height and weight or psychological covering domain cognitive, affective, and also psychomotor (Trianto, 2011: 5).

As mentioned Piaget (Trianto, 2011: 10) that every child has their way in understanding and adapt to their cognitive skill (theory). According to him, every child has an existing cognitive structure called schemata the system a have in mind as a result understanding towards an object that is in the neighborhoods. Understanding of the object lasting through the process of assimilating connecting (object to the concept is already present in mind) and accommodation of (the process concepts in the mind to interpret objects). Both the process if ongoing will make old knowledge and knowledge was a balanced. Thus gradually the can build their knowledge through interaction of learning and behavior is strongly influenced by aspects of himself and its environment. They are imposible to be separated. 


\section{RESEARCH METHOD}

The method chosen is a quasiexperiment this research involving two classes experiment and control where both classes are given pretest and posttest. Experiment class was taught using discovery learning, and control class using conventional learning. Before giving the both classes treatment is the provision of a pre-test early, after that to knoe student's ability the researses held posttest. Treatment given according to design research Ruseffendi (2010: 53) described as follows: The entire population of TK B Pelangi Kasih City Pematangsiantar and the conditions they chose were not random samples, namely class b1 as the experimental class and class b2 as the control class. was taught using discovery learning, and control class using conventional learning. The sample consisted of 26 students, consisting of 13 boys and 13 girls. Class B1 16 ( 7 boys and 9 girls). 14 B2 class (7 boys and 7 girls).

An instrument used in the study, documentation instrument: observation, interviews and the survey. Data obtained from guidelines, observation, and the survey and by steps his preparation as follows.

1. The preparatory stage

At the preparation, research to submit a proposal research, when a proposal has been approved by then literature study, conducting observations to school, set basic subjects of applied in research, then design research instruments, composing rpp (implementation plan learning daily), and make media learning. After that to pilot an instrument on Thursday, January 102019 then the results analyzed that includes: validity, realibility, for data collection and process the results of the tryouts an instrument, then researchers preparing and submit a request for permission research.

2. In the implementation stage

The implementation stage is stage excavation the data more specific by interviewing and hold observation to the process teaching among the, teachers, and child in Pelangi Kasih group b kindergarten in Pematangsiantar. Activities above intended to ease in the stage its implementation, in addition to data needed can unfold consistent with the objectives of researchers. On the implementation of the researchers choose samples to cover aimed at who is determined by each school as much as 2 classes in group $b$, then implement a pretest in the penultimate class to know the ability early students. After obtained test results early we do teaching and learning activities on experiment class given science skill learning by the application of discovery learning method and control class given conventional learning.

3. The evaluation

Evaluation that the effort to measure the results of an activity, program, or project by means of comparison with its intended purpose, and how its achievements (Mulyono, 2009). At the evaluation, researchers conducted a pre test at the start of the research and test the last on the end of the study. The test was applied to knowing the attainment of science and improving skills on the kids through the application of the discovery learning.

\section{RESULTS AND DISCUSSION Results}

This research was conducted in two classes. The experimental class was taught using discovery learning, and the control class was taught using conventional learning. Learning with a scientific approach turns out to be able to provide new nuances for the learning process. Students can find their own scientific concepts by studying rock groups. They have to write everything they find in draft form, be it sizes and the colours. Then students are given time to reconstruct everything that has found into scientific concepts with their scientific skills. The initial step of this learning process is that the child is exposed to various types of stones so that the student has basic concepts about science. The second stage of this process is the search for and discovering science concepts through testing healthy 
and unhealthy drinks so that children will recognize and analyze and discover science concepts with discovery learning methods. The third stage of the learning process is to name and find colors according to the concepts they have.

To measure the science skills which taught using discovery learning and conventional learning, the researchers provides science skills tests at the beginning and at the end. By using the discovery learning method for eight meetings, the students' science skills can be increased. As for the science skills tested, among others: intellectual discovery and procedures, understanding the representation of the same concept, looking from one procedure to another.

\section{Charts 1}

\section{The average capability pretest science} skill experiment class

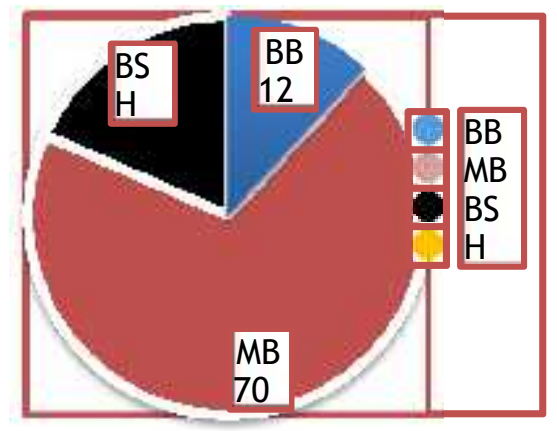

From graph 1 above, it can be seen that from the results of the pretest, $12 \%$ of students' science skills did not develop, $18 \%$ of students' science skills developed as expected, and $70 \%$ of students' science skills began to develop, compared to students who were not taught by the discovery learning method.

After student learned use discovery leaning, from posttest we know that $2 \%$ paud undeveloped (BB), $91 \%$ began to develop (MB), and $7 \%$ on development develops as expected (B S H), so we can conclude that there is an increase student's science skills development from the time prior to treatment and after the treatment in skills through the application of discovery learning method

\section{Discussion}

Research done at 10 January 2019 to May 2019. Population of this research is all of student class b1 (5-6) a year in year by the 2018/2019 consisting of 14 boys and 14 girls, with the total students 28 participants. To know results successful and not his then required analysis and discussed in this section. Testing hypothesis research conducted using special software data processing and the 25 spss Microsoft office excel. Following the score skill served statistics science students through the application of discovery learning method.

Before implemented research, first performed pretest done with the observations on experiment class and control class. The results obtained on class first showed that before the application of the discovery learning on experiment class obtained data that sciences skill to children group b in kindergarten bhayangkari 42 Bandung is low, because observations obtained is as follows: there are $(0 \%)$ child in $\mathrm{BB}$ criteria, $(73 \%)$ is to a criterion $\mathrm{MB}$, to a criterion BSH there are (27\%), and to a criterion BSB (0\%). In science skill in the application of discovery learning method children in kindergarten Pelangi Kasih prior to the adoption of a method of experiment on experiment class no better than my students who received connventional learning. The experiment class received approaches to discovery learning as treatment methods, the control class received connventional learning obtain lessons learned. Research on class steps all experiments using visual learning constructed media-media adapted to the characteristics of the approach it in accordance with a visual learning media control and his learning activities be conducted by ways of listening to teachers talk or oriented to teachers. The data used to the analysis of the final stage of this research is the post-test scores of experiment class. The data analyzed in the end of the study, of the calculation of the results of the experiment after applied on group b (5-6 years old) as well as the control group b (5-6 years old). Based on the results of the analysis regarding the 
posttest data between experiment class and control class, the results show that science skills of the students of experiment class with greater good of a class based on n-gain control and the results of the analysis that there has been increasing skill science students who received learning by using the discovery learning method.

Observations in kindergarten Pelang Kasih, science skill learning focus on drawing, coloring, the paper and pencil color pushes who makes children fast bored and made them pause to study science, and found playing only rewards given to them when done duty. Learning skill and science is supposed to served in the context of the activity of playing, through the pleasing agreed with Pratiwi (2016 learning) that science in kindergarten for children and training to explore to a nearby object. Science this needs a skill that is comfortable and grant freedom for children. Thus there needs props or medium surrounding objects on the learning and draw to the. The result of research shows that the achievement of science learning skills with regular learning methods given in kindergarten Pelangi Kasih need to get further evaluation, because methods used have not taken a significant positive impact. Because the real skill this science is one of the ability of important and useful in the daily life, almost all activity in the daily life cannot be separated from science. This is in accordance with that put forward by Mirawati (2017), that science including the introduction of the concept of the child can help encounter and processes in the science lessons for children not to be a medium used to stimulate the development and maximize potential children themselves. Because that is, usage method of interest to the skills needed to grow and develop, this science is so vital skills mastery of this science is that would be useful for the lives of children generation to come. This shows that skills to children in kindergarten Pelangi Kasih when pretest remain low Category This was an indication that stimulation provided less effective both for the to age group and the control group experiment.
Stimulation on child in kindergarten Pelangi Kasih done with very limited media and children less able to exploring with thing the package, learning science skill is given only limited of your class. The condition of the end of science skill children in kindergarten Kevin in the experiment after the implementation of the application of a method of discovery learning, show an increase significant. This condition based on data posttest that 2 percent of students paud an undeveloped (BB), $91 \%$ flourishing (MB), and $7 \%$ are in the development of grow according the hope (BSH). An increase in significant differences, is because the differences in the provision of stimulation provided. In the control group given stimulation with a method of conventional learning, while in group experiment given stimulation with use the application of a method of discovery learning. This method is one of strategy used childrend to can learn science in more fun.

The use of the application of this method aims to improve the skill science. It is the same with what expressed by Muliani, et al (2017) that this excess method: 1) knowledge gained through this method ground so that it, remembered by an 2) the a children and the delight at which the investigate and succeeded, 3 ) drives the to think and work up the initiative, 4) learning child-centered active and teachers out, ideas they 5) can develop mastery skill and the cognitive process of children. Of some of the more on hence a method in discovery just applied to develop skill science. Steps in the application of discovery learning method activities done in research was attended the skill with the science. These aspects among others know quantity objects, pictures, find and know form and me. The result of research, change is starting to become apparent after treatment fifth. Children group experiment have start getting to know the form of, smoothly in said forms, not confused back at should mention a form of igneous rock if shown forms original. Can be classified kind of small and the great stone. Stimulation the application of a method of discovery learning this shows a significant 
increase and more effective in improving intelligence children. This is further strengthened by research conducted by Muliani, et al in 2017 on the impact of mixing learning discovery method to color. Results that it is instructed the learning methods he continued that emphasizes the students to find your own that. So are teachers or parents must have ability to choose stimulation right moment in skill science to early childhood. Based on the results of the analysis skill science students were still difficult is the indicators forms small know rocks. Second-class still experienced difficulty, the difficulty for the students is hard in interpret know and find small things shaped. According to sukirman (Rahardjo, Warih \& amp, Parta; 2016:382) occurring because the less students their mastery of the material. Research on through the application of skill science discovery method learning to are still fire several limitations. And several limitations this study of them are:

1. No review of the science relating to skill. 2. A very limited, used researchers when the researchers for the treatment and use the data which will posttest longer or more accurate data.

3. The total sample each class a little.

\section{CONCLUSION}

Characteristic of a device developed according to syntax learning methods of discovery learning consisting of three steps, the preliminary phase 1) inception work includes digging knowledge the apersepsi material in keeping with the theme, phase 2) discovery learning the core problems as the theme, the tools and materials, discovery/experiment by students, question and answer the findings / experiment, and do lka, phase 3) analysis covering the activities learning material drawing conclusions, reflection of the teachers, and to the teacher motivation. Whether device learning methods of discovery learning to understanding the science can be seen from the increase in cognitive learning outcomes of children and their activities in learning process. Their activities in learning is very good. The study results afterwards applied cognitive learning methods of discovery learning seen a significant increase in applied in before.

\section{REFERENCES}

Arikunto, S. 2006. The evaluation of education (revision). Jakarta: Bumi Aksara.

Balim, A. G. 2009. The Effects of Discovery Learning on Students' Success and Inquiry Learning Skills. Egitim Arastirmalari Eurasian Journal of Educational. Vol 35, Hlm: 120.

Budiningsih. (2015). Model Discovery Learning. Jakarta: Pustaka Mandiri.

Catherine, G. M. 2012. Early Childhood Education for the Pre-School Age Going Children: The Issue of Low Enrolments in Kenya. Journal of Education and Practice. Vol 3, No 6, Hlm: 48

Hobri. 2009. Methodology research development (developmental research). Jember: universitas jember.

Masitoh. 2005. Learning active approach in a kindergarten. Jakarta: Depdiknas.

Mirawati, N. R. (2017). Improved the skills science process early childhood through gardening activity. Journal education: Early Childhood. Vo. 1 No. 1 Tahun 2017.

Mulyono, A. (2009). Education for children performs a learning 
disability. Jakarta: Rineka Cipta.

Pratiwi, D. (2016). Increase the process of science with the guided discovery to group $b$ tk salafiyah pleret bantul. Math and science education journal.

Rahardjo, S., Parta I., \& Sitaresmi. (2016). Increased capacity connection mathematicals through learning cycle $5 \mathrm{e}$ to the matter theorem phythagoras class VIII. Journal JPM.

Roestiyah, N. K. 2012. Teaching and learning strategy. Bandung: Rineka Cipta.
Russeffendi, E. T. (2010). Basic research education and other non eksakta field. Bandung: Tarsito

Santana, F. D. T., Ekasari, D. (2019). The science and technology on the science in a kindergarten. Journal cheerful.

Trianto. 2011. The design of the development of thematic learning. Jakarta: Kencana Prenada Media Group. 
40 JURNAL PENDIDIKAN EDUTAMA, Vol. 8, No. 1 Januari, 2021 